dation that plasma volume estimations should be a part of routine clinical investigation cannot be accepted.

\section{W G REDMAN}

Lecturer in Obstetric Medicine,

John Radcliffe Hospital,

Oxford OX3 9D4

' Hytten FE, Paintin DB. Increase in plasma volume during normal pregnancy. Fournal of Obstetrics and Gynaecology of the British Commonwealth 1963;70:402-7.

2 Pirani BBK, Campbell DM, MacGillivray I. Plasma volume in normal first pregnancy. Fournal of Obstetrics and Gynaecology of the British Commonwealth $1973 ; 80: 884-7$.

${ }^{3}$ Rovinsky JJ, Jaffin $\mathrm{H}$. Cardiovascular hemodynamics in pregnancy. I. Blood and plasma volumes in multiple pregnancy. Am $\mathcal{Y}$ Obstet Gynecol 1965;93:1-15.

4 Fullerton WT, Hytten FE, Klopper AI, McKay E. A case of quadruplet pregnancy. Fournal of Obstetrics and Gynaecology of the British Commonwealth $1965 ; 72: 791-6$.

${ }^{5}$ Duffus GM, MacGillivray I, Dennis KJ. The relationship jetween baby weight and changes in maternal weight, total body water, plasma volume, electrolytes and proteins and urinary oestriol excretion. fournal of Obstetrics and Gynaecology of the British Commonwealth 1971;78:97104.

${ }^{6}$ Gruenwald P. Growth of the human fetus. II. Abnormal growth in twins and infants of mothers with diabetes, hypertension, or isoimmunization. Am f Obstet Gynecol 1966;94:1120-32.

7 Cope I. Plasma and blood volume changes in pregnancies complicated by pre-eclampsia. Fournal of Obstetrics and Gynaecology of the British Commonwealth $1961 ; 68: 413-6$.

${ }^{8}$ Chesley LC. Plasma and red cell volumes during pregnancy. Am $\mathcal{f}$ Obstet Gynecol 1972;112:440-50.

${ }^{9}$ Bing RF, Smith AJ. Plasma and interstitial volumes in essential hypertension: relationship to blood pressure. Clin Sci 1981;61:287-93.

${ }^{10}$ Gallery EDM, Hunyor SN, Györy AZ. Plasma volume contraction: a significant factor in both pregnancy-associated hypertension (preeclampsia) and chronic hypertension in pregnancy. $Q \mathcal{F}$ Med 1979;48: 593-602.

${ }^{11}$ Arias F. Expansion of intravascular volume and fetal outcome in patients with chronic hypertension and pregnancy. Am J Obstet Gynecol 1975; $123: 610-6$.

${ }^{12}$ Studd JWW, Blainey JD, Bailey DE. Serum protein changes in the preeclampsia-eclampsia syndrome. Fournal of Obstetrics and Gynaecology of the British Commonwealth 1970;77:796-801.

${ }^{13}$ Horne CHW, Howie PW, Goudie RB. Serum alpha ${ }_{2}$-macroglobulin, transferrin, albumin, and IgG levels in preeclampsia. 8 Clin Pathol $1970 ; 23: 514-6$

${ }^{14}$ Chesley LC. Hypertensive disorders in pregnancy. New York: AppletonCentury-Crofts, 1978:215-9.

${ }^{15}$ Henshall WR. Differences in albumin distribution and dynamics between toxaemic and non-toxaemic pregnant women. Br $\mathcal{f}$ Obstet Gynaecol $1979 ; 86: 463-7$

${ }^{16}$ Benedetti TJ, Carlson RW. Studies of colloid osmotic pressure in pregnancy-induced hypertension. Am F Obstet Gynecol 1979;135:308-11.

17 Liley AW. Clinical and laboratory significance of variations in maternal plasma volume in pregnancy. Int $\mathcal{f}$ Gynaecol Obstet 1970;8:358-62.

${ }^{18}$ Lund CJ, Donovan JC. Blood volume during pregnancy. Significance of plasma and red cell volumes. Am F Obstet Gynecol 1967;98:393-403.

19 Koller O, Sandvei R, Sagen N. High haemoglobin levels during pregnancy and fetal risk. Int f Gynaecol Obstet 1980;18:53-6.

${ }^{20}$ Cloeren SE, Lippert TH. Effect of plasma expanders in toxemia of pregnancy. N Engl f Med 1972;287:1356-7.

${ }^{21}$ Hobbs JB, Oats JN, Palmer AA, et al. Whole blood viscosity in preeclampsia. Am $\mathcal{F}$ Obstet Gynecol 1982;142:288-92.

${ }^{22}$ Buchan PC. Preeclampsia-a hyperviscosity syndrome. Am $\mathcal{f}$ Obstet Gynecol 1982;142:111-2.

${ }^{23}$ Brewer TH. Administration of human serum albumin in severe acute toxaemia of pregnancy. Fournal of Obstetrics and Gynaecology of the British Commonwealth 1963;70:1001-4.

${ }^{24}$ MacLean AB, Doig JR, Aickın DR. Hypovolaemia, pre-eclampsia and diuretics. Br $\mathcal{F}$ Obstet Gynaecol 1978;85:597-601.

${ }^{25}$ Assali NS, Holm LW, Parker HR. Systemic and regional hemodynamic alterations in toxemia. Circulation 1964;29, 30, suppl 11:53-7.

${ }^{26}$ Hamilton HFH. Cardiac output in hypertensive toxaemias of pregnancy. fournal of Obstetrics and Gynaecology of the British Empire 1951; 58:977-84.

${ }^{27}$ Parving H-H, Rossing N, Nielsen SL, Lassen NA. Increased transcapillary escape rate of albumin, $\mathrm{IgG}$, and $\mathrm{IgM}$ after plasma volume expansion. Am F Physiol 1974;227:245-50.

${ }^{28}$ Goodlin R, Holdt D, Woods R. Pregnancy-induced hypertension associated with hypervolemia: case report. Am $\mathcal{F}$ Obstet Gynecol 1982;142: 114-5.

29 Goodlin RC, Dobry CA, Anderson JC, Woods RE, Quaife M. Clinical signs of normal plasma volume expansion during pregnancy. Am f Obstet Gynecol 1983;145:1001-9.

\section{Changing American medicine}

Dramatic changes are taking place in American medicine. In October 1983 the United States government changed the way it reimburses hospitals for Medicare patients (those aged over 65), but the change will eventually affect patients of all ages. The full effects of this new method of reimbursement will become apparent only with time, but the initial reaction of the health professions does allow speculation on the future of medicine in the United States.

By tradition doctors have been accustomed to using their discretion and judgment both in diagnosing and treating patients and in billing for their services. Hospital charges were designed to cover their costs and to generate a modest surplus. In 1965 the United States government introduced Medicare. Hospitals were reimbursed under part A, "covering reasonable costs," and doctors were allowed to make a "reasonable charge" under part B. As might have been predicted, the absence of reimbursement ceilings led to inflation at a rate considerably greater than in other sectors of the economy - though much of the increased cost was due to increased services. In 1983 health care costs in the United States had risen to $\$ 300$ billion ( $£ 200000$ million) a year, over $10 \%$ of the gross national product. The United States government pays for $40 \%$ and large employers $30 \%$ of the total bill for health care.

Recent changes in the health market place are now exerting pressure on the providers. The demand for hospital beds is diminishing; fewer were occupied in 1982 than 1981. Hospitals generally are losing their monopoly on many forms of health care-and thus are experiencing an erosion of their economic base. For example, much simple surgery is now performed in "surgicenters," which are not necessarily affiliated with hospitals. There is now an excess of doctors in the United States, 18000 new graduates having entered medical practice in 1983 alone. Doctors' net disposable incomes have declined steadily since 1975 . American consumers believe that they have a right to good health care and a right to live. They have come to expect expensive, high technical diagnostic procedures (such as computed tomography) and therapeutic measures such as coronary bypass surgery, renal dialysis, and transplants. Malpractice suits are increasing, pushing insurance premiums ever higher. Doctors are being forced to practise expensive defensive medicine. The United States population is aging and so making increasing demands on the delivery of health care.

In 1982 the United States government responded to pressure to control the costs of health care by passing the Tax Equity and Financial Responsibility Act, which-for the first time-placed a ceiling on reimbursement of hospital costs and redefined the doctors' services which were reimbursable as a hospital cost. The mechanism chosen to accomplish this goal was a system of prospective payments based on diagnosis related groups-a comprehensive set of 467 medical classifications initially developed at Yale University. Hospitals will now be reimbursed for each individual patient's stay at a rate determined by the discharge diagnosis; the actual length and cost of the stay are not taken into account. The sum paid for each diagnostic group is determined by a branch of the United States government, the Health Care Financing Administration. A three year phasing in period has begun, during which reimbursement will be shifted gradually from an emphasis on the hospital's costs, via a rate structure based on nine geographic regions, to a strict 
dependence on a national scale allowing only for differences in rural and urban costs. The Department of Health and Human Services is studying the extension of the prospective payment approach to include doctors' fees and reimbursement by private insurers.

All the services provided to a patient in hospital will be included under the diagnosis related group payment. No separate charges can be made. Professional review organisations will be required to monitor unnecessary readmissions and other abuses of the diagnosis related group programme. The cost of medical education and of capital equipment will be a "pass through" cost for the first three years, but eventually these costs, too, seem likely to be reimbursed under diagnosis related groups.

The central concept in this new system is that a hospital will be allowed to keep the difference if its costs are less than the reimbursement calculated for the diagnosis related groupbut it will have to absorb any excess costs. The belief is that hospitals will be forced to improve the efficiency and cost effectiveness of their services. Radiology departments, for example, which were previously revenue generating areas will now become closely scrutinised cost centres. Attempts will be made to limit the excessive use of laboratory tests, and laboratories should become much more cost efficient. The emphasis in laboratory testing will be on producing a diagnosis rather than a test result. The clinical pathologist should have a key role in developing new attitudes and approaches. Hospitals will also seek sources of revenue outside direct patient care. They will attempt to pool their resources with other health care delivery systems to improve their productivity and cost efficiency. The mix of different diagnoses in patients will be critical, since reimbursement on diagnosis related groups varies with discharge diagnosis. Administrators and hospital staffs will have to work closely together to meet these challenges. The hospitals will closely monitor the type of patient admitted, the length of stay, and the performance of each member of the attending staff.

Preadmission laboratory testing is likely to be used more widely, for it is not reimbursed under diagnosis related groups, and the patient's stay in hospital will not be prolonged by waiting for laboratory results. Testing after discharge is also likely to increase for the same reasons. Laboratories will be forced to operate 24 hours a day, seven days a week to accommodate shorter hospital stays.

There will be more competitive bidding for services throughout the health care system in order to cut costs. This may lead to a decline in the quality of care, because fewer skilled workers will be hired, costly quality control activities will be curtailed, continuing medical education will be limited, and test development will become too costly.

Americans have become increasingly aware of the cost of medicine in the past decade. In the next few years they are likely to have greater flexibility in choosing methods for paying for this care. They will continue to demand high quality but affordable medicine.

CURTIS L BAKkeN

Head, Section of Regional Laboratory Services, Department of Laboratory Medicine

Donald S Young

Head, Section of Clinical Chemistry, Department of Laboratory Medicine

Mayo Clinic,

Rochester,

Minnesota 55905,

USA

\title{
Hyperbaric oxygen for patients with multiple sclerosis
}

\author{
J MERTIN, W I MCDONALD
}

\begin{abstract}
Multiple sclerosis is still poorly understood and has no established treatment. Disturbances in immunoregulatory mechanisms have been thought to indicate that autoimmunity may play an important part in the pathogenesis. Over the past two decades attempts at devising curative treatment have concentrated on trials of immunosuppression or immunopotentiation. Recently, however, claims have been made for treatment with hyperbaric oxygen. The rationale for this approach is, in part, the superficial similarity between the clinical features of decompression sickness and multiple sclerosis-but the range of symptoms which arise from dysfunction of the central nervous system is narrow, and similarities in clinical symptoms do not imply pathogenetic identity.
\end{abstract}

The partial pressure of oxygen in the arterial and venous blood may be raised substantially by breathing pure oxygen above normal atmospheric pressure. Such hyperoxygenation may be achieved with the help of hyperbaric oxygen pressure chambers, of which there are two types. In monoplace chambers a single patient can be bathed in pure oxygen but is removed from the direct attention of medical personnel, which might have serious implications if the patient developed complications, such as a convulsion. Another disadvantage is that some patients develop severe claustrophobia. ${ }^{1}$ Several patients may be treated in walk in multiplace chambers, and they may be accompanied by trained attendants. In such chambers oxygen is delivered with the help of facemasksbut these often leak in the sealing area around the face and 